\title{
Legitimacy of Teaching English Composition as a Non-Native Speaker
}

\author{
Ayşe Naz Bulamur \\ Department of Western Languages and Literatures, Boğaziçi University, Istanbul, Turkey \\ *Corresponding Author: naz.bulamur@boun.edu.tr
}

Copyright (C) 2013 Horizon Research Publishing All rights reserved.

\begin{abstract}
I examine how American students respond to foreign instructors, who teach English Composition and Research Writing. I discuss how minority teacher's cultural, lingual, and ethnic differences interfere with classroom dynamics in the United States. I rely on my experiences as a Turkish instructor of composition at the University of Wisconsin, Milwaukee (2004-2010) to talk about how international teaching instructors have the position of authority in classroom.
\end{abstract}

Keywords International Teaching Assistants, English Composition, Contact Zone, and Ethnicity

\section{Introduction}

The purpose of this project is to examine how non-native speaker instructors have the position of authority in teaching English Composition in the United States. Lucy Jacobs and Charles Friedman, Fred Fitch and Susan Morgan, Indira Karamcheti, and Jacinta Thomas have already demonstrated that most undergraduate students question the credibility and teaching skills of the foreign instructor. They observe that student complaints are inseparable from the Orientalist discourse that associates the West with reason and power, and the East with irrationality and inferiority. Students tend to evaluate their teacher's performance in relation to his or her accent, skin color, nationality, and cultural background. I claim that the minority teacher's degree of linguistic and ethnic differences determine how "foreign" he or she is perceived in a classroom of predominantly white American students. The Southeast Asian, South American, and African teachers, for example, might be seen as more "foreign" than European teachers. Within this context, I examine how my accented English, and white female Turkish identity might be perceived while teaching English Composition as a teaching assistant at the University of Wisconsin, Milwaukee. By comparing my teaching experiences with that of the Indian Professors'-Karamcheti and Thomas-I illustrate how students' perception of a foreign teacher is constructed by their racial and ethnic prejudices. I argue that the reason why the students do not question my authorial position in class is perhaps because my ethnic differences may not be as "visible" compared to that of Indian and Asian teaching assistants".

\section{Discussion}

Roland Barthes [1] argues that the body consists of an "image-repertoire" of socially constructed stereotypes, adjectives, and significations. He asks: "What is the 'you' you might or might not look like? [...] Where is your authentic body? [...] you are condemned to the repertoire of its images." "You" is condemned, for Barthes, because the body is never authentic and neutral, but social and political. Carla Peterson [2] also writes that the "body is never simply matter, for it is never divorced from perception and interpretation." Teacher's credibility and authority in class depend on how his or her race, gender, nationality, and language are perceived by the students. My body's "image-repertoire"-white skin, dark hair, young complexion, and accented English-is also subject to students' interpretations from the moment I walk into the classroom. As Barthes [3] would suggest, it is highly possible that my white foreign body and accent interfere with our classroom dynamics and even control "social communication."

\section{1. "Language Zone" in Composition Classroom}

My accented English is the most visible image that makes me "Other" in class. Even though most students perceive me as a white Caucasian female, my accent signifies my minority status in a classroom where majority of students are native speakers of English. American students might question how a non-native speaker can be the credible source of information in a writing course. The minority teacher might also suspect his or her own ability to teach composition. For example, George Braine [4] writes how he questioned his authority to teach Freshman Composition at 
the University of Texas as a non-native speaker of English from Sri Lanka.

Somewhat demoralized by my new identity as a NNS, I was startled to learn that I would have to teach a first year writing course to native speakers. Teach writing? Unaware of current writing pedagogy, even of the process approach, I walked into each class meeting embarrassed and insecure, doubtful if I was even the proverbial one step ahead of my students.

Braine's identity as a non-native speaker diminished his self-esteem and made him feel embarrassed and insecure to teach writing. Unlike Braine, I have never been demoralized to teach a writing course as a non-native speaker. However, I was worried that the students at UWM would not be comfortable with a Turkish instructor teaching English composition. From English 101 students, I was expecting the question of how a non-native speaker can have the authority to teach composition to American students.

Jacobs and Friedman [5] point out how international teaching assistants receive student complaints because of their lack of English proficiency:

Students complain that foreign
instructors do not have adequate control
over productive and receptive oral skills.
Mispronunciation of sounds,
misplacement of stress, and faulty
intonation patterns may contribute to
student noncomprehension. In addition,
students cite the inability of some
instructors to understand their oral
questions and comments. These basic
language-related complaints are believed
to create major interference that may
hinder the student learning process.

Mispronunciation of words and faulty intonation are images that make the teacher's body "foreign" in classroom. However, what exactly prohibits students' learning process remains unclear. Is there a lack of communication in class due to the instructor's accent? Or do students resist classroom activities because of the minority teacher whose race and ethnicity are visibly different? We should also consider the possibility that students' resistance to the foreign instructor might itself hinder the learning process. Students' refusal to participate in class activities and study the course material might prevent them from learning. In this case, students' resistance to and intolerance of difference might be a "major interference" in the learning process.

Fred Fitch and Susan E. Morgan [6] also point out how the international teaching assistant's accent becomes an excuse for students at a southern state university for not being able to understand the subject matter. They write that students tend to construct a negative identity of the minority teacher as "the unintelligible ITA" when the subject matter is itself unintelligible. For example, if they have difficulty with understanding calculus or physics, they blame the ITA for not having native like pronunciation. "The unintelligible ITA" is the "common tale" among undergraduates:

I have to have another international T.A. that I can't understand. ...It really upset me. And so, I stood up and said, 'You people are horrible.'

You can't understand them and you can't comprehend anything they say ... You don't know what they are talking about and they can't understand you.

What is problematic in these narratives is that we do not exactly know who the students refer to with the terms "you people" and "they." Are they building a binary between "we," Americans, and "they," the foreigners, on the basis of the instructor's accent and/or on her racial and ethnic differences? Would they consider white foreigners as "horrible" as the teacher of color? I do not think so. As a white foreign teacher, I have never received any student complaints due to my accent. Perhaps the reason why my students are not upset to have a minority teacher is because they do not perceive my race and appearance as being different. For this reason, I believe that the degree of the teacher's difference determines how foreign she is perceived in class. It is more likely that the non-Caucasian and non-native speaker teacher becomes the scapegoat for the students' inability to learn and to receive a lower grade.

The myth of "the unintelligible ITA" also becomes problematic as James Paul Gee [7] states that not only the language, but also the interpretive community of the teacher constitutes her "image-repertoire" in class. As Braine questions whether he is the "proverbial one step ahead of [his] students" as a non-native speaker, Gee suggests that not linguistic competence, but acquisition of discourse makes him a recognizable source of authority in classroom:

At any moment we are using language we must say or write the right thing in the right way while playing the right social role and (appearing) to hold the right values, beliefs, and attitudes. Thus, what is important is not language, and surely not grammar, but saying (writing)—doing—being_valuing-belie ving combinations. These combinations I call "Discourses." [...] Discourses are ways of being in the world; they are forms of life which integrate words, acts, values, beliefs, attitudes, and social identities [...] A Discourse is a sort of 'identity kit' which comes complete with the appropriate costume and instructions on how to act, 


\section{talk, and often write, so as to take on a particular role that others will recognize.}

As Gee points out, not only the accented English, but also attitudes, social values, education level constitute the "identity kit" of the foreign instructor. For example, not only my accent, but also my social role as a teaching assistant pursuing her Ph.D. in Literary Studies might affect the students' evaluation of my teaching skills. As the students perceive me as an "insider" to the academic discourse, they grant me the authority to teach critical reading and writing practices.

With my teaching practices, I imply that my ostensible lack of fluency in spoken English will not hinder their learning process in English 101. I underline the fact that my role as a foreign instructor is not to teach the grammar rules of their native language, but to help them engage in critical reading/writing practices. The focus of my composition classroom is not linguistics or punctuation, but the use of language in a meaningful and coherent way. In other words, I do not teach them "what [to] say, but how [to] say it" [8]. Most of the native speaker students in class do not know how to express themselves in an appropriate way in written language. For example, in their essays, many students refer to the authors, Christopher Lasch and Haunani-Kay Trask, as "a man named Lasch," and "a girl from Hawaii." The following passage from my student's paper demonstrates Gee's idea that one can follow the grammar rules, but still not make sense.

\section{For example you might have a boy that is a punk rocker and dresses punkish, and on the other hand a girl who is very upscale and dresses preppy. They like each other and have a certain connection that you might not see unless you hang out with them. There are many connections I made between Geertz, Trask, and Lasch.}

Instead of correcting the grammar and punctuation mistakes in this passage, I encourage the student to establish a stronger connection between the three writers. I ask: "How do you relate the example of punk rocker and the upscale girl to Geertz, Trask and Lash?" My comments suggest that comparing writers to punk rockers is grammatically correct, but not "the right way" of using language while playing the "social role" of being a college student studying academic writing.

Both in my written comments and in class discussions of sample student papers, I emphasize that revision is not about correcting grammar mistakes, but about re-seeing and rethinking about the research project. For example, as the class focuses on how the student writer uses the word "about" three times in one sentence, I shift their attention to the writer's ability to situate his perspective in relation to the authors. My oral and written comments emphasize that I give priority not to grammar and punctuation, but to content, structure, clarity, and controlling purpose in writing. As the students focus on producing a critical interpretation of a text by providing different points of view and convincing interpretations, they see that they are not trained in English grammar, but in "social practices" of the academic discourse.

However, shifting the focus from language to discourse does not make the foreign instructor's accent invisible. It is evident that I make grammar mistakes while talking to the students. I do not have a native-like pronunciation either. For this reason, there might be times when students have difficulty in understanding what I am saying in class. It is significant to note that accented English is just one among many images that constitute my "identity kit" in the classroom. Pursuing Ph.D. in Literary Studies, focusing on critical thinking instead of grammar in class, and being an insider to the academic discourse also constitute my "image-repertoire." If body is social, as Barthes writes, my classroom practices might lead students to perceive me not only as a foreigner, but also as a member of the academic community.

\section{2. "Contact Zone" in Composition Classroom}

I have already pointed out that not only the instructor's accent, but also her skin color and cultural background might affect her authority in English Composition class. However, Fitch and Morgan [9] indicate that nationality and ethnicity of the teacher come secondary for students. They believe that students have "global perception" of the international teaching assistants' identity: "What matters is simply that they are foreign." They argue that students construct a negative ITA (international teaching assistant) identity no matter which race or culture they associate the foreign instructor with. In contrast to Fitch and Morgan, Indira Karamcheti [10] argues that students' perception of ITAs is not "global" and "universal," but varies depending on “"surplus visibility' of race and ethnicity" of the instructor. As an Indian instructor, she complains that most students stereotypically associate whiteness with culture, rationality, and sophistication: "We are the local and regional opposed to the universality of the West, nature to its culture, instinct to its intellect, body to its brain."

Karamcheti shows that students' perception of a white European instructor and a teacher of color may not be identical as Fitch and Morgan have argued. The students' prejudice that non-Caucasians are not as intelligent as Westerners might lead them to question the authorial position of the teacher of color. For example, Karamcheti's [11] English Composition students were shocked to have an Indian T.A at the University of California, Santa Barbara. Her students even informed her that the table at front of the classroom was "meant for the teacher." Jacinta Thomas [12] tells us how her students' hierarchical binary between the West and the local leads them to question her reliability as an Indian professor. She writes that her Indian identity was her "baggage" she carried as she entered every class: "It is not unlike the insecurity experienced by many U.S. academics of color, who "carry the colony wherever [they] go." Unlike 
Thomas, I do not feel that my Turkish identity is a "baggage" I carry with me to class. In the first day of classes, the students are probably surprised to have a Turkish instructor teaching English Composition. However, they never make me feel that I am not sufficient and knowledgeable enough to teach writing. Perhaps the reason why my students grant me the authority to teach composition is that they perceive me as a white, Caucasian, and a European female teacher. In other words, my social and cultural differences may not be as "visible" as that of the teacher of color.

According to Karamcheti [13], one of the potential roles available to the minority teacher is to render racial and ethnic differences invisible and to speak with "the master's voice:" "The minority teacher can cast himself or herself as the traditional authoritarian personality, the hard-driving, brilliant, no-nonsense professional for whom the personal- [race and ethnicity] — has nothing to do with anything." Excluding one's "image-repertoire" and presenting oneself as an objective and professional teacher is what Karen Kopelson [14] calls as "performance of neutrality." She argues that race, gender, and ethnicity of the teacher are subject to students' examination and interpretation. She remarks that since students assume that classroom is an objective, and apolitical space, they see teacher's racial or sexual difference as an intrusion to their "'neutral' course of study." She proposes that "performance of neutrality" is a pedagogical tactic that enhances tolerance for difference and reduces students' resistance to the foreign teacher. The minority teacher will shift from her "a priori" position — feminist, homosexual, and etc.- -and pretend to be objective and impartial. In other words, the teacher will try to conceal her political standpoint and ethnic differences. Kopelson [15] assumes that this will challenge students' identity-based presumptions and will help them be open to differences. If the marginalized teacher distances herself "from students and the subject matter" and performs the "disinterested, academic, authoritative role," students will cease to question the authoritative position of the minority teacher.

As opposed to Kopelson's "performance of neutrality," Karamcheti [16] advocates "performance of race," which "means to make race visible" in class. She argues that racial and ethnic differences of the teacher are "irrepressible," and will inevitably affect classroom dynamics. Instead of concealing cultural differences, as Kopelson suggests, Karamcheti [17] asks minority teachers to encourage their students to think "how much 'race' is made by social expectations and constructions." Simone Alexander [18] also explains how she cannot possibly perform neutrality as a black, Caribbean-born female professor while teaching African-American literature and English Composition. She enhances tolerance for her racial difference by choosing texts "that embrace and celebrate difference and otherness." She shows how "the personal"-race and ethnicity-is inseparable from her teaching practices by including texts that promote diversity.

I agree with Karamcheti and Alexander that linguistic and cultural differences are irrepressible and impossible to conceal. I cannot shift from my "a priori" position - non-native speaker and Turkish instructor - with my accented English, and pretend to be American. Not concealing the differences, but making them visible in class helps students acknowledge and embrace diversity. As Karamcheti suggests, minority teachers can make the best use of their differences by showing how racial and cultural stereotypes are socially constructed. In fact, English 101 readings at UWM encourage minority teachers to prefer "performance of race" to "performance of neutrality." For example, by reading Haunani-Kay Trask's "From a Native Daughter" and Clifford Geertz's "Common Sense as a Cultural System," students witness how racial and ethnic stereotypes are historically and socially determined. Students become more perceptive to the cultural differences after reading Geertz's essay on how common sense is shaped by one's cultural system. I can make the best use of my lingual and national differences by highlighting the educational value of multicultural classroom environment where students are exposed to different points of view. Perceiving various cultural systems not as "right" and "wrong," but just different from one another might lead students grant the position of authority to the minority teacher.

Whether the foreign instructor performs race or neutrality, teaching itself is a performance that is shaped by internal as well as external factors. Katherine Hendrix, Ronald Jackson, and Jennifer Warren [19] argue that not only personal — race, ethnicity, accent etc.-but also external factors, such as administrative expectations and environmental settings of universities shape ITAs' teaching practices: "Student/teacher relationships are far bigger than classroom interaction; they are impacted by the departmental, institutional and societal climate." In this case, not only cultural differences, but also external factors such as, pedagogy courses, orientation, and mentor groups are a part of the foreign instructor's "equipment" with which she teaches writing. Starting from the orientation, ITAs at the University of Wisconsin-Milwaukee learn the teaching philosophy in American universities, which might be very different from their educational background.

\section{Conclusion}

Overall, the minority teacher's "image-repertoire"-accent, skin color, and ethnicity-has political significations. Karamcheti and Thomas show that the teacher's skin color determines whether she is perceived as an insider to the academic discourse. The students might question the minority instructor's teaching skills because they correlate reason and knowledge with the Caucasian and not with the teacher of color. Following Gee's argument, I believe that not my linguistic differences, but my "identity kit" as an English teacher and a Ph.D. student helps me to be perceived as the credible source of information in teaching composition as a non-native speaker. If my cultural and 
ethnic differences had been more visible, my students could have challenged my reliability as a foreign instructor as well. I hope that my students enjoy the social space "where cultures meet, clash, and grapple with each other" [20]; and that their multicultural classroom environment enhances their critical reading and writing abilities.

\section{REFERENCES}

[1] Roland Barthes, Barthes by Barthes, trans. Richard Howard (Berkeley: University of California Press, 1994), 34.

[2] Qtd. in Simone Alexander, "Walking on Thin Ice; The Il/legitimacy of Race and Racial Issues in the Classroom," in The teacher's body: embodiment, authority, and identity in the academy (2003): 108.

[3] Roland Barthes, Barthes by Barthes, trans. Richard Howard (Berkeley: University of California Press, 1994), 137.

[4] George Braine, "From the Periphery to the Center: One Teacher's Journey," in Non-Native Educators in English Language Teaching, ed. George Braine (New Jersey: Lawrence Erlbaum Associates, Publishers, 1999), 21.

[5] Lucy Cheser Jacobs, and Charles B. Friedman, "Student Achievement under Foreign Teaching Associates Compared with Native Teaching Associates," Journal of Higher Education 59 (1988): 552.

[6] Fred Fitch, and Susan E. Morgan, "'Not a Lick of English': Constructing the ITA Identity Through Student Narratives," Communication Education 52 (2003): 302-303.

[7] James Paul Gee, "Literacy, Discourse, And Linguistics: Introduction,” Journal of Education 171 (1989): 6-7.

[8] James Paul Gee, "Literacy, Discourse, And Linguistics: Introduction,” Journal of Education 171 (1989): 5.
[9] Fred Fitch, and Susan E. Morgan, "'Not a Lick of English': Constructing the ITA Identity Through Student Narratives," Communication Education 52 (2003): 301.

[10] Indira Karamcheti, "Caliban in the Classroom," Radical Teacher 44 (1993): 13.

[11] Indira Karamcheti, "Caliban in the Classroom," Radical Teacher 44 (1993): 14.

[12] Jacinta Thomas, "Voices from the Periphery: Non-Native Teachers and Issues of Credibility," Non-Native Educators in English Language Teaching, ed. George Braine (New Jersey: Lawrence Erlbaum Associates, Publishers, 1999), 10.

[13] Indira Karamcheti, "Caliban in the Classroom," Radical Teacher 44 (1993): 16.

[14] Karen Kopelson, "Rhetoric on the Edge of Cunning; Or, The Performance of Neutrality (Re)Considered As a Composition Pedagogy for Student Resistance," College Composition and Communication 55 (2003): 117.

[15] Karen Kopelson, "Rhetoric on the Edge of Cunning; Or, The Performance of Neutrality (Re)Considered As a Composition Pedagogy for Student Resistance," College Composition and Communication 55 (2003): 127.

[16] Indira Karamcheti, "Caliban in the Classroom," Radical Teacher 44 (1993): 17.

[17] Indira Karamcheti, "Caliban in the Classroom," Radical Teacher 44 (1993): 17.

[18] Simone Alexander, "Walking on Thin Ice; The Il/legitimacy of Race and Racial Issues in the Classroom," The teacher's body: embodiment, authority, and identity in the academy (2003): 105-118.

[19] Katherine Grace Hendrix, Ronald L. Jackson, and Jennifer R. Warren, "Shifting Academic Landscapes: Exploring Co-Identities, Identity Negotiation, and Critical Progressive Pedagogy," Communication Education 52 (2003): 180.

[20] Mary Louise Pratt, "Arts of the Contact Zone," Profession (1991): 34 